Методика розвитку критичного мислення студентів засобами дослідницького навчання в процесі викладання курсу історії

УДК 378:37.013.3

\title{
МЕТОДИКА РОЗВИТКУ КРИТИЧНОГО МИСЛЕННЯ СТУДЕНТІВ ЗАСОБАМИ ДОСЛІДНИЦЬКОГО НАВЧАННЯ В ПРОЦЕСІ ВИКЛАДАННЯ КУРСУ ІСТОРІЇ
}

\author{
Наталія Шалашна \\ кандидат історичних наук, доцент кафедри \\ культурології, естетики та історії \\ ДВНЗ «Донбаський державний педагогічний університет», \\ м. Слов'янськ, Україна \\ ORCID ID E-1715-2018 \\ n.shalashna@gmail.com \\ Володимир Проскунін \\ кандидат педагогічних наук, доцент, \\ проректор з науково-педагогічної роботи \\ і соціально-економічного розвитку, \\ ДВНЗ «Донбаський державний педагогічний університет», \\ м. Слов'янськ, Україна
}

\begin{abstract}
Анотація. У статті проаналізовано можливості розвитку критичного мислення студентів в умовах організації дослідницького навчання на прикладі курсу історії. Простежено принципові ознаки дослідницького навчання та визначено методологічні взаємозв'язки цих принципів із ключовими компетентностями критичного мислення. Здійснено поетапний аналіз процесу викладання в умовах дослідницького навчання та простежено, які саме навички критичного мислення формуються й розвиваються на кожному з цих етапів. Визначено, які можливості розкриває історія як навчальна дисципліна для розвитку критичного мислення. Зокрема, відзначено поліваріативність історичного знання, сполучення конкретного фактографічного матеріалу та можливостей його креативної інтерпретації як важливу передумову критичного мислення. Запропоновано конкретні методичні прийоми, які доцільно організовувати на кожному з етапів навчання з метою розвитку критичного мислення.

Ключові слова: критичне мислення; дослідницьке навчання; історична освіта; вища освіта.
\end{abstract}

Постановка проблеми в загальному вигляді. Уміння мислити критично - одна 3 ключових вимог до реалізації успішної професійної кар'єри та особистісного розвитку в умовах сучасного світу. Саме тому розвиток в учнів критичного мислення є важливим завданням Нової української школи. Однак лише той педагог здатний формувати й розвивати в учнів це вміння, який сам на високому рівні його опанував. Тому розробка теоретичних і методологічних засад розвитку критичного мислення в студентів педагогічних вищих навчальних закладів має сьогодні високу актуальність. У процесі вивчення історії здатність до критичного мислення відіграє одну з провідних ролей, бо

() ДВНЗ «Донбаський державний педагогічний університет» 
Методика розвитку критичного мислення студентів засобами дослідницького навчання в процесі викладання курсу історії

повноцінне засвоєння цього навчального курсу передбачає здатність студента робити самостійні висновки та оцінки, формулювати власне ставлення до історичних подій та їхніх учасників. Отже, заняття 3 історії мають значний потенціал щодо розвитку критичного мислення майбутніх педагогів.

Аналіз останній досліджень і публікацій. Проблема розвитку критичного мислення є сьогодні надзвичайно актуальною, тому привертає пильну увагу дослідників. Наразі в педагогічній науці існують сформульовані теоретичні підходи до визначення критичного мислення як складного комплексу психологічних ознак, інтелектуальних і мотиваційних компетентностей, зокрема в працях таких авторів, як А. Кроуфорд, В. Саул, С. Метью, Д. Макінстер, Д. Клустер, О. Пометун, $\quad$ I. Сущенко. Досліджувалась також сутність дослідницького навчання як принципово нової парадигми організації навчального процесу в роботах В. Голобородько, С. Заїр-Бек, І. Муштавінської, Г. Лиходєєвої. Конкретні теоретичні та методичні підходи до розвитку критичного мислення в умовах навчання історії аналізувались такими дослідниками, як Л. Киянко-Романюк， Л. Куземко，Л. Любіченко， П. Мороз, О. Пометун, С. Терно, О. Тісліченко, В. Ткаченко та В. Ягоднікова. Проте поза увагою дослідників до сьогодні залишається специфіка історичного навчання в контексті можливостей розвитку критичного мислення та перспективи сполучення застосування парадигми дослідницького навчання 3 розвитком критичного мислення як навчальною метою.

Формулювання цілей статті. Метою статті $є$ проаналізувати можливості історії як навчальної дисципліни для розвитку критичного мислення студентів в умовах організованого дослідницького навчання.

Методи дослідження. Дослідження здійснювалось за допомогою методів теоретичного аналізу і синтезу для виявлення сутності критичного мислення як психолого-педагогічної категорії та дослідницького навчання як прогресивної педагогічної технології, процесу викладання історії як комплексу навчальновиховних заходів; концептуально-порівняльного аналізу для співставлення змісту основних компетентностей критичного мислення, можливостей дослідницького навчання та специфіки історичного знання.

Результати дослідження. Говорячи про критичне мислення, мається на увазі цілий комплекс інтелектуальних умінь, практичних навичок, знань, психологічних характеристик тощо. Визначити, яка 3 цих складових $\epsilon$ вирішальною в здатності особистості критично мислити, неможливо, бо сукупність та ієрархія компонентів, які становлять основу для реалізації цієї здатності, глибоко індивідуальна. Проте зафіксувати наявність і ступінь 
Методика розвитку критичного мислення студентів засобами дослідницького навчання в процесі викладання курсу історії

розвитку в індивіда здатності мислити критично цілком можливо, бо реалізація цієї здатності передбачає конкретний результат. Цим результатом $\epsilon$ формулювання обгрунтованих висновків та оцінок, прийняття рішень на основі самостійно обраних розумових стратегій та операцій із використанням наявного комплексу знань (Кроуфорд, 2006). При цьому обгрунтування висновків, оцінок і рішень може відбуватись лише в системі наукового світогляду, усі аргументи й твердження мають бути доведеними 3 використанням усталених в науці методологічних підходів. Критичне мислення також передбачає суворе дотримання принципу об'єктивності. Крім того, критичне мислення має спиратись на самостійну розумову діяльність (Пометун, 2012).

Розуміючи здатність до критичного мислення як систему, із педагогічного погляду, у ній можна виділити окремі здатності та вміння. Це насамперед здатність виявляти в конкретній ситуації дослідницьку проблему, вловлювати ії суть, усвідомлювати, у якій науковій площині лежить комплекс питань, що їх необхідно вирішити (Киянко-Романюк, 2004). Виявлення проблеми передусім вимагає таких компетентностей, як: розуміння змісту висловлювання, здатності виділяти одиницю інформації та встановлювати зв'язок між компонентами інформаційного повідомлення. Визначення наукової площини дослідницької проблеми вимагає достатнього рівня фактографічних знань і певного рівня сформованості наукового світогляду. Важливе значення має також здатність розчленувати проблему на складові для іiі комплексного та поетапного вирішення. На цьому етапі необхідним є сформоване вміння ставити запитання, формулювати інформаційний запит.

Наступним компонентом здатності до критичного мислення як комплексу компетентностей $\epsilon$ навичка пошуку інформації для вирішення проблеми. Ї̈̈ формування й розвиток насамперед передбачає розуміння системи наукового знання, сформоване уявлення про взаємозв'язок між різними науковими дисциплінами, усвідомлення відмінності між об'єктивною та суб'єктивною інформацією, уміння визначати міру достатньої для вирішення проблеми інформації тощо (Любіченко, 2014). Пошук інформації передує іiі аналізу й синтезу та перевірці. Володіння інтелектуальними операціями аналізу й синтезу $\epsilon$ важливою передумовою розвитку критичного мислення.

Серед складових компетенції критичного мислення важливе місце належить умінню формулювати гіпотези та оцінювати альтернативи вирішення проблеми або здатність проаналізувати інформаційний потенціал різних варіантів відповіді на запитання. Для цього необхідною передумовою $є$ навичка до наукового прогнозування та здатність до креативного мислення (Ткаченко, 
Методика розвитку критичного мислення студентів засобами дослідницького навчання в процесі викладання курсу історії

2014). Гіпотеза як відповідь на запитання є за своєю суттю новим знанням, тому креативність як риса особистості $є$ необхідною умовою здатності до критичного мислення.

Завершальною частиною критичного мислення як комплексу компетенцій особистості є здатність приймати самостійні рішення та обгрунтовувати власний вибір. Обгрунтування власної думки $\epsilon$ окремою $\mathrm{i}$ дуже важливою компетентністю, яка включає в себе розуміння причинно-наслідкового зв'язку між подіями, фактами, умовиводами, здатності чітко й послідовно сформулювати власну думку, усвідомлення категорій необхідності та достатності, володіння основами логічного мислення тощо. Здатність приймати самостійні рішення та робити свідомий вибір вимагає розвинутої саморефлексії, відповідальності як риси особистості, цілісності індивідуальності.

Окрім того, критичне мислення передбачає певні мотиваційні передумови, серед яких варто виділити зацікавленість у вирішенні поставленої проблеми, очікування користі для колективу та визнання для себе особисто, готовності нести відповідальність за своє рішення та наполегливості в обстоюванні власної думки, орієнтованості на розвиток власної особистості, готовність до саморефлексії та самовдосконалення.

Отже, критичне мислення - це складний комплекс інтелектуальних, вольових, емоційних складових, що передбачає в якості конкретного результату цілком самостійне і науковим чином обгрунтоване судження з певної проблеми (Заїр-Бек, 2004). Розглянемо специфіку формування здатності до критичного мислення в процесі викладання історії у вищій школі. Певні основи здатності до критичного мислення мають бути сформовані ще в середній школі і становлять необхідні передумови подальшого розвитку цієї здатності у вищому навчальному закладі. Йдеться насамперед про володіння певною сумою фактографічних знань, оволодіння якими передбачає шкільна програма, а також про такі вміння й навички, як: сприйняття та первинний аналіз інформації, здатність послідовно виражати власну думку, сформованість основ наукового світогляду тощо.

Водночас здатність до критичного мислення $\epsilon$ характеристикою розвинутої особистості і головним чином має бути розвинута саме у вищому навчальному закладі. Курс історії при цьому є лише однією 3 багатьох навчальних дисциплін, викладання яких серед інших завдань вирішує також $\mathrm{i}$ завдання формування й розвитку критичного мислення. Водночас у процесі викладання історії є можливість значно більше зробити для розвитку цієї важливої складової особистості майбутнього спеціаліста. Якщо предмети 
Методика розвитку критичного мислення студентів засобами дослідницького навчання в процесі викладання курсу історії

природничо-математичного циклу передбачають аксіоматичність знання і для критичного мислення як креативної здатності тут майже не залишається місця, то дисципліни гуманітарно-естетичного та соціального спрямування передбачають множинність поглядів і майже не мають остаточних дефініцій, а тому критичне мислення в парадигмі цих галузей значно забарвлене емоційністю та суб’єктивністю. Натомість історичні дисципліни, зберігаючи об'єктивну чіткість фактографічної інформації, дозволяють значну інтелектуальну самостійність в інтерпретації фактів, що дає широкий простір для критичного мислення (Пометун, 2016).

Відповідно викладання історії у вищій школі здатне надати дуже широкий простір для формування критичного мислення. У якості методологічного підходу до організації викладання, що має найкраще забезпечити вирішення цих завдань, можна запропонувати розроблену вітчизняними науковцями концепцію дослідницького навчання (Куземко, 2007). Самостійно отримане наукове знання передбачає оволодіння студентами вмінням самостійно створювати творчий освітній продукт, під яким розуміються як інтелектуальні, так і практичні результати навчально-дослідницької діяльності, які можна охарактеризувати як суб'єктивно нове знання. Саме такий підхід до організації навчально-виховного процесу може забезпечити водночас ефективне опанування курсу історії як однієї з навчальних дисциплін та розвиток особистості студента як життєво важливу мотиваційну установку.

Для реалізації завдання розвитку критичного мислення в процесі викладання історії засобами дослідницького навчання необхідно у відборі змісту та засобів викладання забезпечити дотримання певних вимог. Насамперед необхідно забезпечити належну мотивацію не лише до засвоєння навчального курсу, а й до оволодіння здатністю критичного мислення (Люходєєва, 2007). Мотиваційним чинником до цього є передусім властива молоді потреба в самостійному пізнанні довколишнього світу й особистісному самоствердженні, проте історичне знання дає вагому мотиваційну складову до розвитку критичного мислення через демонстрацію історичних прикладів утвердження тоталітарних режимів, небезпеки релігійного фундаменталізму, відставання в економічному та соціальному розвитку людських суспільств, гальмування наукового прогресу через відсутність у багатьох членів суспільства здатності до критичного мислення. Так формується усвідомлення критичного мислення як однієї з передумов індивідуального успіху та однієї з гарантій суспільного прогресу та об'єктивного покращення умов життя, що виступає могутнім мотиваційним стимулом до оволодіння цією компетентністю. 
Методика розвитку критичного мислення студентів засобами дослідницького навчання в процесі викладання курсу історії

Наступним етапом організації навчального процесу, який забезпечує розвиток критичного мислення в процесі викладання курсу історії, $є$ побудова змістовного компонента не як сукупності знань, які необхідно засвоювати, а як сукупності питань, на які необхідно дати відповідь для подальшого успішного функціонування суспільства (Мороз, 2012). Від викладача така постановка питання вимагає послідовної реалізації певних вимог.

По-перше, необхідно виявити в структурі фактографічного знання, передбаченого для засвоєння, проблемні питання, які водночас були б посильними для вирішення студентами та відрізнялись актуальністю для сьогодення.

По-друге, слід ретельно проаналізувати ці питання, відкинувши занадто політично актуальні або такі, що можуть викликати несприйняття студентами певних релігійних конфесій або етнічних груп. Крім того, оскільки йдеться про навчально-дослідницьку діяльність, питання повинні мати вирішення хоча б у найближчому наближенні, бо навряд чи доцільно пропонувати студентам ті проблеми, до яких ще не брались або від яких відмовились фахівці.

По-третє, потрібно розмістити обрані питання в структурі курсу пропорційно, урахувавши необхідність опанування студентами різних видів навчальної діяльності та формування всього комплексу необхідних навичок. Мається на увазі, що дослідницькі проблеми мають бути вмонтованими як у текст лекцій, так і в питання семінарських і практичних занять, тематику самостійної роботи, різні види позааудиторної роботи тощо.

На завершальному етапі варто передбачити оцінювання результатів дослідницької роботи студентів та надання можливостей представити ці результати як самостійний здобуток у вигляді участі в конкурсах, роботи в наукових гуртках, підготовки виступів на студентських наукових конференціях тощо.

Так, дослідницьке навчання має стати базовим середовищем для розвитку критичного мислення. При цьому слід постійно мати в полі зору головну характеристику дослідницької діяльності - її творчий характер та систематичну організацію роботи за певними стандартизованими методиками. Така діяльність має принципові відмінності в організації мислення - мислення здійснюється через чіткі механізми аналізу й синтезу та не має бути емоційним. Під час дослідницької діяльності результат не є відомим заздалегідь, він може лише передбачатись і виступає результатом індивідуальної творчості (Терно, 2011).

При цьому в процесі навчання дослідницька діяльність студентів не має на меті створення нового в суспільному значенні знання, а лише опанування 
Методика розвитку критичного мислення студентів засобами дослідницького навчання в процесі викладання курсу історії

майбутнім спеціалістом певною сукупністю навичок з освоєння дійсності як об'єкта пізнання в науковій парадигмі. Водночас дослідницька діяльність в умовах вищої школи розкриває для студентів значно ширші можливості - вони можуть не лише в процесі опанування функціональними навичками розширити свої здібності, але й брати участь у повноцінних наукових дослідженнях, які проводяться науковцями. Так, до розвитку критичного мислення студентів ставляться ще вищі вимоги: випускник вищої школи має бути не лише здатним критично осмислювати отриману інформацію та приймати практичні рішення, але й перебувати повсякчас у процесі наукового пошуку, оцінюючи досягнення інших та свої власні з погляду їхньої відповідності сучасним викликам.

Завдання розвитку критичного мислення в умовах дослідницького навчання в згорнутому вигляді повторює основні етапи дослідницької діяльності, а саме: постановку проблеми, вивчення наявної інформації, висування гіпотези, відбір методів вирішення проблеми, збір та аналіз інформації, іiі узагальнення й власне рішення. Так, дослідницька діяльність і критичне мислення постають у тісному зв'язку, де успішне опанування навичками критичного мислення дозволяє адекватно реалізувати кожний з етапів дослідницького процесу, а на завершальному етапі оцінити дослідницькі результати. Тобто критичне мислення водночас постає як необхідна складова наукового світосприйняття та конкретний інструмент дослідницької діяльності.

Усе сказане вище є справедливим для всієї системи навчання у вищій школі: будь-яка навчальна дисципліна серед своїх завдань має розвиток критичного мислення, бо сам процес навчання відбувається в умовах наукової парадигми пізнання. Проте історичне знання розкриває деякі специфічні можливості для розвитку критичного мислення не лише в змісті навчального матеріалу, але й у системі методичних прийомів (Ткаченко, 2014). Оскільки критичне мислення водночас $\epsilon$ парадигмальною ознакою світосприйняття сучасної освіченої людини та конкретним інструментом пізнання світу, варто відбирати засоби навчально-виховного впливу відповідно до цього принципу.

Навчальний курс з історії має бути побудований як системна дослідницька робота з вирішення проблемних питань і водночас стимулювати застосування студентами навичок критичного мислення на кожному етапі навчання. Так, на етапі формулювання проблемних питань, які будуть вирішуватись упродовж вивчення навчальної дисципліни, розпочати варто з актуалізації опорних знань, здобутих у процесі шкільного навчання. Цей етап за своєю суттю передбачає відтворюючу навчальну діяльність, проте i тут можна стимулювати до критичного осмислення наявних знань, зокрема через завдання визначити 
Методика розвитку критичного мислення студентів засобами дослідницького навчання в процесі викладання курсу історії

наслідки тих чи тих подій і процесів для сьогодення. Після цього можна вже запропонувати студентам сформулювати питання, які будуть вирішуватись у процесі вивчення курсу. Стимулюючи індивідуальну творчість студентів, водночас варто запропонувати їм загальні напрямки мислення, наприклад, визначення впливів на вітчизняну історію загальноєвропейських i загальносвітових подій, дослідження впливу розвитку ідей на розвиток суспільства, з’ясування ролі особистості в історії, дослідження поліетнічної та поліконфесіональної історії (Ягоднікова, 2009).

Власне, ці напрямки являють собою найбільш перспективні вектори переосмислення парадигми національної історії, отже, студенти водночас виявляють власні творчі здібності та знайомляться із загальними течіями історичної науки. Із методичних прийомів на цьому етапі з погляду розвитку критичного мислення найкраще застосовувати мозковий штурм, кластери, хмаринку тегів тощо, адже на цьому етапі завдання полягає в усвідомленні проблеми та пошуку іiі складових. Організувати таку роботу можна як під час інтерактивного лекційного заняття, так і під час семінарського заняття.

Визначивши загальну проблему, можна переходити до наступного етапу: пошуку шляхів іi вирішення. На цьому етапі головним завданням є пошук інформації для вирішення проблеми (Пометун, 2012). Залежно від того, наскільки об’ємне обране студентами питання, воно може вирішуватись упродовж одного або кількох модулів навчання, а може бути дослідницьким завданням на весь курс навчання. Відповідно пошук інформації має різну тривалість і глибину. Проте навіть за умови пошуку відповіді на нескладне ситуативне питання необхідно вимагати дотримання основних принципів наукового пошуку. Курс історії з огляду на вирішення цього завдання подає надзвичайно багаті можливості для опанування студентами навички наукового інформаційного пошуку.

На відміну від будь-якої іншої науки, історія в якості джерел інформації оперує практично всіма різновидами артефактів, які породжує людське суспільство в процесі свого розвитку. Відповідно пошук серед історичних джерел надає студентам навички як аналізу фахової наукової літератури, так $\mathrm{i}$ знайомство з специфікою різноманітних документів, зокрема й особистісного характеру, а також із різноманітними проявами людської культури. Для розвитку критичного мислення дуже важливе значення має необхідність перевіряти інформацію 3 історичних джерел, усвідомлювати можливу суб'єктивність авторів, їхню упередженість, відрізняти помилкову інформацію від справжньої тощо (Тісліченко, 2015).

Професіоналізм педагога: теоретичні й методичні аспекти. - Вип. 11. - Слов’янськ, 2019. 
Методика розвитку критичного мислення студентів засобами дослідницького навчання в процесі викладання курсу історії

У процесі пошуку інформації студенти мають змогу водночас розширити фактографічні знання та опанувати ключову для критичного мислення установку обов’язкової перевірки даних і методики цієї перевірки. 3 метою розвитку практичних навичок критичного мислення варто стимулювати студентів здійснювати інформаційний пошук послідовно за всіма групами історичних джерел, але не хаотично, а в послідовності, яка задається рівнем об'єктивності інформації. На цій шкалі на одному полюсі будуть фахові наукові дослідження, на іншому - безпосередні спогади учасників подій. Залежно від конкретних завдань можна розпочинати з будь-якого з цих полюсів, але варто провести студентів по всім градаціям об'єктивності, продемонструвавши таким чином важливість ретельної перевірки інформації. Для вирішення цих завдань варто використовувати методичні прийоми, які сполучають індивідуальну та групову роботу.

У сучасному інформаційному суспільстві успішне опанування навичками критичного мислення вимагає від майбутнього фахівця високого рівня компетентності в системі джерел інформації, їхніх можливостях, принципах поширення інформаційних повідомлень, рівня достовірності інформації в кожній із підсистем (Лиходєєва, 2007). У цьому плані курс історії також дає широке поле для формування й поглиблення вмінь, бо різні види історичних джерел функціонують у різних сферах системи поширення інформації. Зокрема, фахові публікації є частиною наукового інформаційного обігу, джерела усної історії присутні в системі публіцистики та особистісного обміну інформацією, документація різного роду є частиною офіційного інформаційного потоку.

У процесі роботи з цими джерелами в студентів $є$ можливість зрозуміти відмінності між цими системами та принципи пошуку в них. Формами організації навчальної роботи, під час яких найкраще може бути реалізований інформаційний пошук, мають виступати насамперед самостійні форми роботи в сполученні з семінарськими та практичними заняттями. Причина цього в тому, що швидкість інформаційного пошуку багато в чому залежить від індивідуальних психічних особливостей, водночас для розвитку критичного мислення важливо забезпечити глибоке засвоєння кожним студентом цього вміння (Куземко, 2017). Результати ж інформаційного пошуку варто обговорювати в групі, зокрема на семінарських заняттях, бо самостійно дати оцінку достатності та глибини отриманої інформації досить важко.

Наступним етапом роботи в умовах дослідницького навчання $є$ аналіз та узагальнення інформації. На цьому етапі студенти мають опанувати одну 3 ключових компетентностей критичного мислення: виділення головного, 
Методика розвитку критичного мислення студентів засобами дослідницького навчання в процесі викладання курсу історії

систематизація та узагальнення. Формування цієї компетентності є досить складним завданням, бо вимагає високого рівня розвитку цілого комплексу вищих інтелектуальних та психічних здібностей, тому на цьому етапі знов необхідна значна допомога викладача. На початку цієї роботи варто якомога більше унаочнити процес аналізу та систематизації інформації за допомогою різного роду таблиць, схем, графіків тощо. Складання таких схем може бути як самостійним, так і груповим завданням, але обов'язково 3 обговоренням критеріїв узагальнення, обгрунтування вибору принципів порівняння, які застосовуються. Історична наука дає для цього дуже зручний методологічний інструментарій, зокрема синхронний та діахронний методи історичного дослідження (Ягоднікова, 2009). Їх паралельне застосування дає можливість всебічно розглянути проблему та виявити всі їі системні ознаки.

Системність інтелектуальної діяльності передусім $\epsilon$ необхідною передумовою розвитку критичного мислення. Методичними прийомами, які найкраще використовувати для цих цілей, є різноманітні графічні організатори, наприклад, концептуальні таблиці, технологія «товстих» і «тонких» запитань, конспектування за ключовими словами, коментований конспект тощо. Організаційно цей вид роботи варто організовувати в умовах семінарських $\mathrm{i}$ практичних занять. Позитивні результати дає також використання сучасних інформаційних технологій, зокрема обговорення проблеми на тематичних форумах, у групах соціальних мереж, на платформах дистанційного навчання. Такі форми роботи дають можливість унаочнити не лише результати узагальнення матеріалу, але й особистий внесок кожного студента в роботу.

Наступним етапом організації дослідницького навчання з метою розвитку критичного мислення $є$ висування гіпотези, іiі перевірка та формулювання власної точки зору (Клустер, 2006). На цьому етапі найголовнішим завданням $\epsilon$ розвиток такої компетенції критичного мислення, як креативність, здатність до створення нового знання. Те саме $є$ і принципом дослідницького навчання, тому саме в умовах навчально-дослідницької роботи ця компетенція розвивається найкраще. Історичне знання передбачає широкий простір для авторської інтерпретації за умови дотримання принципу наукової об’єктивності та фактографічної обгрунтованості. Тому в процесі засвоєння навчального курсу історії з'являється можливість розвинути вказану компетентність саме в контексті критичного мислення, тобто сполучаючи індивідуальну креативність із усталеними методологічними принципами наукового дослідження.

3 метою посилення вказаного впливу варто запропонувати студентам кілька точок зору видатних науковців на ту проблему, яку студенти 
Методика розвитку критичного мислення студентів засобами дослідницького навчання в процесі викладання курсу історії

досліджували, і дати можливість оцінити якість їхньої аргументації. Безумовно, методичними прийомами, які слід використовувати на цьому етапі, $\epsilon$ різноманітні форми індивідуального висловлювання в сполученні 3 його обговоренням у групі: діалог, конференція, диспут, виступ від імені історичного діяча, наукове есе, захист реферату або повідомлення, круглий стіл тощо. Саме за умови публічного захисту своєї думки студенти опановують такі важливі складові компетентності критичного мислення, як: усвідомлення багатоваріантності знання, відсутність єдиного й остаточно правильного погляду, необхідність постійного розвитку та самовдосконалення (Терно, 2011). Для цього важливо забезпечити продовження історичної самоосвіти студентів і після завершення ними навчального курсу, зокрема в студентських наукових гуртках, спеціалізованих наукових спільнотах, у краєзнавчій роботі тощо.

Висновки 3 дослідження і перспективи подальших розвідок у цьому напрямі. Проведене дослідження засвідчило, що історія як навчальний курс має певну специфіку, яка надає широкі перспективи для розвитку критичного мислення, а саме:

- сполучення чіткості фактографічного матеріалу з різноманітністю його наукової інтерпретації;

- різноманітність історичних джерел, що передбачає збагачення навичок інформаційного пошуку та аналізу;

- хронологічність розташування матеріалу як методологічну вимогу, чим забезпечується розвиток системності мислення;

- поєднання впливу глобальних процесів із роллю особистості в історії, що забезпечує розвиток навички розуміння відмінності між об'єктивним та суб'єктивним у науковому знанні.

Ці перспективи якнайкраще розкриваються в умовах дослідницького навчання. Структура дослідницького навчання передбачає послідовне формулювання проблеми, пошук необхідної інформації та іï перевірку, наукову обробку інформації, висування гіпотези та іiі перевірку, формулювання результатів та їхню аргументацію. Усі ці інтелектуальні операції передбачає і навичка критичного мислення в згорнутому вигляді, чим обгрунтовується методологічна виправданість формування й розвитку критичного мислення як однієї з цілей дослідницького навчання. На кожному із етапів дослідницького навчання можна запропонувати конкретні методичні прийоми, які найкраще відповідають меті розвитку критичного мислення. У перспективах подальших досліджень проаналізувати змістовне наповнення курсу історії у вищому навчальному закладі з погляду його відповідності цілям розвитку критичного 
Методика розвитку критичного мислення студентів засобами дослідницького навчання в процесі викладання курсу історії

мислення.

\title{
СПИСОК ВИКОРИСТАНИХ ДЖЕРЕЛ
}

1. Голобородько, В. і Гнєдашев, В. (2005). Наукова робота учнів. Програма організації науково-дослідницької діяльності учнів (с. 58-61). Харків, Україна: Основи.

2. Заир-Бек, С. И. и Муштавинская, И. В. (2004). Развитие критического мылиления на уроке. Москва, Российская Федерация: Просвещение.

3. Киянко-Романюк, Л. А. (2004). Зарубіжна і національна практика розвитку критичного мислення в учнів і студентів. Вища освіта України, 4, 109-113.

4. Клустер, Д. (2005). Что такое критическое мышление? Критическое мышиление и новые виды грамотности (с. 5-13). Москва, Российская Федерация: ЦГЛ.

5. Кроуфорд, А., Саул, В., Метью, С. і Макінстер Д. (2006). Технології розвитку критичного мислення учнів. Київ, Україна: Вид-во «Плеяди».

6. Куземко, Л. В. (2017). Проблема формування у майбутніх педагогів критичного мислення та здатності вирішувати проблеми. Молодий вчений, 3(43), 417-421.

7. Лиходєєва, Г. В. (2007) Навчально-дослідницькі уміння та дослідницька діяльність учнів у психолого-педагогічній літературі. Дидактика математики: проблеми та дослідження, 27, 89-94.

8. Любіченко, Л. В (2014). Створення сприятливого навчального середовища для розвитку критичного мислення на уроках історії. Історія та правознавство, 27, 2-8.

9. Мороз, П. В. (2012). Дослідницька діяльність учнів в процесі навчання історї України: Методичний посібник. Київ, Україна: Педагогічна думка.

10. Пометун, О. I. (2012). Методика розвитку критичного мислення на уроках історії. Історія і суспільствознавство в школах України, 1, 3-7.

11. Пометун, О. і Сущенко, I. (2016) Основи критичного мислення: методичний посібник для учителів. Київ, Україна: Ліра.

12. Терно, С. (2011). Чому важливо розвивати критичне мислення учнів? Iсторія в школах Украӥни, 10, 30-34.

13. Тісліченко, О. А. (2015). Розвиток критичного мислення учнів на уроках історії при вивченні діяльності історичних осіб. Таврійський вісник освіти, 3(51), 230-235.

14. Ткаченко, В. М. (2014). Розвиток критичного мислення учнів на уроках історії як умова їхньої успішної соціалізації. Таврійський вісник освіти, 1(2), 141-151.

15. Ягоднікова, В. В. (2009) Застосування технології розвитку критичного мислення у процесі професійної підготовки майбутніх фахівців. Вісник післядипломної освіти, 11, 190196.

\section{METHODOLOGY OF DEVELOPING CRITICAL THINKING OF STUDENTS BY RESAERCH EDUCATION IN THE PROCESS OF TEACHING THE HISTORY COURSE}

\author{
Nataliia Shalashna \\ Candidate of Pedagogical Sciences, Associate Professor of \\ the Department of Culture Studies, Ethics and Aesthetics \\ SHEI "Donbas State Pedagogical University" \\ Sloviansk, Ukraine \\ ORCID ID E-1715-2018 \\ n.shalashna@gmail.com
}

Професіоналізм педагога: теоретичні й методичні аспекти. - Вип. 11. - Слов'янськ, 2019. 
Методика розвитку критичного мислення студентів засобами дослідницького навчання в процесі викладання курсу історії

\title{
Volodymyr Proskunin
}

\author{
Candidate of Pedagogical Sciences, Associate Professor, \\ Vice-rector for scientific and pedagogical work \\ and socioeconomic development, \\ SHEI "Donbas State Pedagogical University" \\ Sloviansk, Ukraine
}

\begin{abstract}
The development of critical thinking is a necessary requirement for qualitative higher education. Critical thinking refers to a set of motivational impulses, intellectual skills and skills that, as a result, provide the subject with the ability to ask a question independently, search and analyze information, make and justify a decision. However, historical education has its own specificity, which contributes to the development of the necessary competencies of critical thinking.

Analysis of publications. Today, in pedagogical science there are formulated theoretical approaches to the definition of critical thinking and research teaching in the works of such authors as A. Krouford, D. Kluster, O. Pometun, I. Sushchenko, S. Zair-Bek, L. Liubichenko, P. Moroz and others.The purpose of this article is to analyze the possibilities of history as a course for the development of students' critical thinking in the context of organized research training.

In the structure of critical thinking, you can distinguish individual capacity and skills: the ability to identify a problem for research in a particular situation, the ability to find and analyze information, the ability to make independent decisions and justify their choice.

Historical courses, while maintaining the objective clarity of factual information, allow for considerable intellectual autonomy in the interpretation of facts, which gives a wide scope for critical thinking. As a methodological approach to the organization of teaching, it is possible to offer the concept of research training developed by domestic scientists. Each stage of study should provide opportunities for self-search and creativity of students. Among the methodical techniques, the best effect shows the combination of individual work and public discussion of its results.

History as a training course has the best opportunities for developing critical thinking. The most promising for this should be the conditions of research training, the structure of which broadly corresponds to the basic intellectual operations of critical thinking. The goals of the development of critical thinking must be matched by the content and organizational principles of the course and the choice of specific methodical techniques.
\end{abstract}

Key words: critical thinking; research training; historical education; Higher Education.

\section{REFERENCES}

1. Holoborodko, V. \& Hniedashev, V. (2005). Scientific work of students. Prohrama orhanizatsii naukovo-doslidnytskoi diialnosti uchniv (pp. 58-61). Kharkiv, Ukraine.

2. Zair-Bek, S.Y. \& Mushtavynskaia, Y.V. (2004). The development of critical thinking in the lesson. Moskow, Russia: Prosveshchenye.

3. Kyianko-Romaniuk, L.A. (2004). Foreign and national practice of developing critical thinking in learners and students. Vyshcha osvita Ukrainy, 4, 109-113.

4. Kluster, D. (2005). What is a critical thinking? The critical thinking and new types of literacy, (pp. 5-13). Moskow, Russia: TsHL.

5. Krouford, A. \& Saul, V. \& Metiu, S. \& Makinster D. (2006). Technologies for the development of students' critical thinking. Kyiv, Ukraine: Vyd-vo «Pleiady».

6. Kuzemko, L.V. (2017). The problem of the formation of future teachers of critical thinking and the ability to solve problems. Molodyi vchenyi, 3(43), 417-421.

7. Lykhodieieva, H. V. (2007) Educational and research skills and research activity of students in psychological and pedagogical literature. Dydaktyka matematyky: problemy ta doslidzhennia, 27, 89-94.

() ДВНЗ «Донбаський державний педагогічний університет» 
Методика розвитку критичного мислення студентів засобами дослідницького навчання в процесі викладання курсу історії

8. Liubichenko, L. V (2014). Creating a supportive learning environment for developing critical thinking in history lessons. Istoriia ta pravoznavstvo, 27, 2-8.

9. Moroz, P.V. (2012). Research activity of students in the process of learning the history of Ukraine: A guide. Kyiv, Ukraine: Pedahohichna dumka.

10. Pometun, O.I. (2012). Methods of developing critical thinking in history lessons. Istoriia $i$ suspilstvoznavstvo $v$ shkolakh Ukrainy, 1, 3-7.

11. Pometun, O. i Sushchenko, I. (2016) Fundamentals of Critical Thinking: A Toolkit for Teachers. Kyiv, Ukraine: Lira.

12. Terno, S. (2011). Why is it important to develop students' critical thinking?. Istoriia $v$ shkolakh Ukrainy, 10, 30-34.

13. Tislichenko, O.A. (2015). Development of students' critical thinking in history lessons when studying the activities of historical persons. Tavriiskyi visnyk osvity, 3(51), 230-235.

14. Tkachenko, V. M. (2014). Developing students' critical thinking in history lessons as a condition for their successful socialization. Tavriiskyi visnyk osvity, 1(2), 141-151.

15. Yahodnikova, V.V. (2009) Application of technology of development of critical thinking in the process of professional training of future specialists. Visnyk pisliadyplomnoi osvity, 11, 190196.

Матеріали надійшли до редакції 26.09.2019 р. 